DZANAIEVA L.S. ${ }^{1}$, DMYTRUK K.V. ${ }^{1}$, SIBIRNY A.A. ${ }^{1,2}$

${ }^{1}$ Institute of Cell Biology, NAS of Ukraine,

Ukraine, 79005, Lviv, Drahomanov str., 14/16, e-mail: dmytruk77@gmail.com

${ }^{2}$ University of Rzeszow,

Poland, 35-601, Rzeszow, Cwiklinskie, 2

$\bowtie$ dmytruk77@gmail.com, (050)661-68-86

\title{
TRANSCRIPTIONAL FACTOR Cat8 IS INVOLVED IN REGULATION OF XYLOSE FERMEN- TATION IN ENGINEERED SACCHAROMYCES CEREVISIAE
}

Aim. The aim of this work is the construction of cat84 strain on the base of xylose-fermenting $S$. cerevisiae strain and evaluation of the xylose fermentation rate. Methods. The CAT8 deletion cassette harboring natNT2 gene flanking with 5' and 3' non-coding regions of CAT8 gene has been constructed. After transformation by the cassette the cat84 strain was selected on the nourseothricin containing medium. Xylose fermentation experiments of constructed strain was performed in mineral medium supplemented with xylose under oxygen-limited conditions. Results. Xylose-fermenting cat $84 S$. cerevisiae strain has been constructed by homologous recombination of the CAT8 deletion cassette with target sequences in the genome of GS010 strain. The cat8 $\Delta$ strain possessed increase in ethanol accumulation, ethanol yield, rate of ethanol production and productivity of ethanol synthesis relative to the parental GS010 strain for 9.5, 6, 20 and $12 \%$, respectively. Conclusions. The mutant of the xylose-fermenting $S$. cerevisiae strain with knock out of the CAT8 gene coding for transcriptional activator, has been constructed. The cat $8 \Delta$ mutant showed $9.5 \%$ increase in ethanol production from xylose relative to parental strain.

Keywords: alcoholic fermentation, xylose, S. cerevisiae, Cat8.

Fluctuation in oil and oil products prices and the prospect of global warming are driving the development of technologies for the production of alternative liquid fuels such as ethanol [1]. Ethanol can be blended with gasoline or used as a neat alcohol in dedicated engines, taking advantage of the higher octane number and higher heat of vaporization; furthermore, it is an excellent fuel for future advanced flexi-fuel hybrid vehicles.

Today biofuel industry primarily produces ethanol from a corn or sugarcane. However, this socalled first generation ethanol produced from starch and sugar, is in competition with a food and animal feed industry. In contrast, lignocellulosic biomass (crop wastes, agricultural and forestry residues, and municipal waste) offers a high potential as feedstock for biofuels, because it is the most abundant sustainable raw material worldwide and occurs as byproduct without competing uses. The following are other advantages of lignocellulose-based ethanol: higher per hectare productivities, generation low net greenhouse gas emissions, reducing environmental impacts, particularly climate change as well as possibility to provide employment in rural areas.

Studies on conversion of lignocellulosics to ethanol focused on the searching for natural microbial strains and construction of recombinants able to ferment efficiently all sugars of lignocellulosic hydrolysates. Effective alcoholic fermentation of xylose, the second abundant after glucose sugar of lignocellulose hydrolysates (consists approx. $30 \%$ of hydrolyzate sugars) is one of the main unresolved problems.

Although there are many bacterial and yeast strains capable of naturally utilizing xylose, Saccharomyces cerevisiae has advantages over the innate xylose-utilizing microorganisms regarding robustness against various stresses in industrial environments, such as low $\mathrm{pH}$, high osmotic pressure, high alcohol concentration, and phage contamination [2].

S. cerevisiae cannot naturally utilize xylose. Metabolic engineering approaches for introducing heterologous xylose utilization pathways and optimizing internal metabolisms have been undertaken to develop efficient xylose-fermenting $S$. cerevisiae strains.

Bacterial or fungal xylose isomerase (XI) pathway catalyzing the isomerization of xylose to xylulose, and heterologous yeast xylose reductase (XR) / xylitol dehydrogenase (XDH) pathway, where xylose is first reduced to xylitol, which is then oxidized to xylulose, have been successfully

\section{${ }^{\circ}$ DZANAIEVA L.S., DMYTRUK K.V., SIBIRNY A.A.}


introduced into $S$. cerevisiae [3]. The main drawback of the XR/XDH pathway consisting in dual cofactor preference for $\mathrm{XR}$ and $\mathrm{XDH}$, was minimized by protein engineering, controlling activity ratio of $\mathrm{XR} / \mathrm{XDH}$, and adding heterologous electron sink reactions [reviewed by 4]. Additional overexpression of the native $S$. cerevisiae genes encoding xylulokinase (XK) and non-oxidative pentose phosphate pathway (PPP) enzymes with subsequent evolutionary engineering enabled anaerobic growth of resulted strains on xylose [5-7].

A positive effect of mutations in the $\mathrm{PHOl3}$ phosphatase gene on xylose fermentation rates in XI- and XR/XDH-based strains has been attributed to transcriptional upregulation of PPP-related genes $[8,9]$. Unspecific phosphatase activity of Pho13 on xylulose-5-phosphate might generate a futile cycle with XK overexpression [10]. Additionally, Pho13 has been implicated in dephosphorylation of the PPP intermediate sedoheptulose-7-phosphate [6].

Xylose enters the yeast cell via hexose transporters, as it does not have specific pentose transporters. Expression of heterologous xylose/hexose transporters has been reported to improve xylose uptake rate in engineered $S$. cerevisiae strains [reviewed by 11]. Also, favorable mutants of homologous hexose transporters Hxt7 (N370S) and Gal2 (N376F) have been reported [12].

Despite of intensive engineering of $S$. cerevisiae strains, xylose fermentation rate still remains lower than for glucose. Therefore, xylose fermentation performance requires improvement.

S. cerevisiae Cat 8 is a $\mathrm{Zn}$-cluster transcriptional activator necessary for expression of genes involved in gluconeogenesis, ethanol utilization and diauxic shift from fermentation to respiration [13, 14]. It was shown that knock out of CAT8 slightly improved glucose fermentation rate in $S$. cerevisiae [15]. Xylose-utilizing S. cerevisiae strains recognize xylose as a respiratory carbon source. Xylose did not fully repress the genes encoding enzymes of the tricarboxylic acid and respiratory pathways, even under anaerobic conditions [16, 17]. As Cat8 responsible for switching from fermentation to respiration, it could be expected that deletion of the gene in the xylose-utilizing $S$. cerevisiae strain will increase of xylose fermentation rate, due to shifting of respiration metabolism to fermentation one. In addition, previous investigations in our laboratory have shown that the deletion on CAT8 gene in naturally xylose-fermenting yeast Ogataea polymorpha increased ethanol production from xylose for 30-50 $\%$ as compared to parental strains [18].
In this study, we report the isolation of cat84 mutant on the background of xylose-utilizing $S$. cerevisiae strain. Constructed strain possessed $20 \%$ increase in xylose fermentation rate when compared to initial strain.

\section{Materials and methods}

The reference S. cerevisiae strain S288C and xylose-utilizing $S$. cerevisiae strain CMB.GS010 (GS010) [17] were used through this study. Yeast cells of $S$. cerevisiae were grown on YPD $(10 \mathrm{~g} / \mathrm{L}$ yeast extract, $10 \mathrm{~g} / \mathrm{L}$ peptone, $20 \mathrm{~g} / \mathrm{L}$ glucose), YPX $(10 \mathrm{~g} / \mathrm{L}$ yeast extract, $10 \mathrm{~g} / \mathrm{L}$ peptone, $20 \mathrm{~g} / \mathrm{L}$ xylose) or mineral medium (6.7 $\mathrm{g} / \mathrm{L}$ YNB without amino acids, $20 \mathrm{~g} / \mathrm{L}$ xylose) at $30^{\circ} \mathrm{C}$. The strain Escherichia coli $\mathrm{DH} 5 \alpha(\Phi 80 \mathrm{~d} l a c Z \Delta \mathrm{M} 15$, recA1, endA1, gyrA96, thi-1, hsdR17( $\left.\mathrm{r}_{\mathrm{K}}^{-}, \mathrm{m}_{\mathrm{K}}{ }^{+}\right)$, supE44, relA1, deoR, $\triangle(\operatorname{lacZYA-\operatorname {arg}F)} \mathrm{U169})$ was used in the part of the experiments that required a bacterial host. The bacterial strain was grown at $37^{\circ} \mathrm{C}$ in $\mathrm{LB}$ medium as described by [19]. The recombinant E. coli strains were grown on medium containing $0.1 \mathrm{~g} / \mathrm{L}$ of ampicillin and agar $(20 \mathrm{~g} / \mathrm{L})$ added to solidify the media.

Alcoholic fermentation of $S$. cerevisiae was fulfilled by cultivation in liquid mineral medium at oxygen-limited conditions at $30^{\circ} \mathrm{C}$. The conditions were provided by agitation at $100 \mathrm{rpm} .40 \mathrm{~g} / \mathrm{L} \mathrm{xy}-$ lose was added into the medium used for the fermentation. The cells were pre-grown in $50 \mathrm{~mL}$ of liquid YPX media in $150 \mathrm{~mL}$ Erlenmeyer flasks at $200 \mathrm{rpm}$ during 24 hours with initial biomass 0.03 $\mathrm{g} / \mathrm{L}$. Then the cells were precipitated by centrifugation, washed by water and inoculated into $25 \mathrm{~mL}$ of the fermentation medium in $150 \mathrm{~mL}$. Erlenmeyer flasks were covered with cotton plugs. The initial biomass concentration for fermentation experiments was $0.3 \mathrm{~g} / \mathrm{L}$. Fermentations were repeated at least in three independent experiments, each performed in triplicate. The bars in the figures indicate the ranges of the standard deviation.

Standard cloning techniques were carried out as described [19]. Genomic DNA of S. cerevisiae was isolated using the Wizard $^{\circledR}$ Genomic DNA Purification Kit (Promega, Madison, WI, USA). Restriction endonucleases and DNA ligase (Fermentas, Vilnius, Lithuania) were used according to the manufacturer specifications. Plasmid isolation from E. coli was performed with the Wizard ${ }^{\circledR}$ Plus SV Minipreps DNA Purification System (Promega, Madison, WI, USA). DNA fragments were separated on a $0.8 \%$ agarose (Fisher Scientific, Fair Lawn, NJ, USA) gel. Isolation of fragments 
from the gel was carried out with a DNA Gel Extraction Kit (Millipore, Bedford, MA, USA). PCRamplification of the fragments of interest was done with Platinum ${ }^{\circledR}$ Taq DNA Polymerase High Fidelity (Invitrogen, Carlsbad, CA, USA) according to the manufacturer specification. PCRs were performed in GeneAmp ${ }^{\circledR}$ PCR System 9700 thermocycler (Applied Biosystems, Foster City, CA, USA). Transformation of the yeast $S$. cerevisiae was carried out as described previously [20].

The biomass was determined turbidimetrically with a Helios Gamma spectrophotometer (OD, $600 \mathrm{~nm}$; cuvette, $10 \mathrm{~mm}$ ) with gravimetric calibration. Concentrations of xylose and ethanol from fermentation in medium broth were analyzed by HPLC (PerkinElmer, Series 2000, USA) with an Aminex HPX-87H ion-exchange column (Bio-Rad, Hercules, USA). A mobile phase of $4 \mathrm{mM} \mathrm{H}_{2} \mathrm{SO}_{4}$ was used at a flow rate $0.6 \mathrm{~mL} / \mathrm{min}$ and the column temperature was $35^{\circ} \mathrm{C}$. Experiments were performed at least twice.

\section{Results and discussion}

Genomic DNA of S. cerevisiae strain S288C strain was used as a template for isolation of $5^{\prime}$ and 3 ' non-coding regions of CAT8 gene by PCR amplifications using primers Ko776 (CCG GAA TTC TGA ATG TGA AAA GGA TCA GAG GCA G) / Ko777 (CAG ATA CAT TAT CTG TGT TGG AAC GGA TCC ATT ATT TGC CAT AAT TTT GTG TCT TG) and Ko778 (CAA GAC ACA AAA TTA TGG CAA ATA ATG GAT CCG TTC CAA CAC AGA TAA TGT ATC TG) / Ko779 (CCC AAG CTT TCA TTG GTC ACT TGA GTT GAT TTG). The resulted 5'CAT8 (762 bp) and 3'CAT8 (922 bp) fragments were combined by overleap PCR with primers Ko776 / Ko779, EcoRI/HindIII double digested and cloned into corresponding sites of vector pUC57 (Fermentas, Vilnius, Lithuania). The resulted recombinant plasmid was named pUC57-Sc_cat8 $\Delta$. Gene natNT2 (1318 bp) conferring resistance to nourseothricin was amplified using vector pRS41N [21] as a template and primers OK19 (CCC AAG CTT GGC GCG CCA GAT CTA TAA CTT CGT ATA GCA TAC ATT ATA CGA AGT TAT CTT AAC TAT GCG GCA TCA GAG) / OK20 (CCC AAG CTT GGC GCG CCA GAT CTA TAA CTT CGT ATA ATG TAT GCT ATA CGA AGT TAT CCG AGA TTC ATC AAC TCA TTG C). Obtained fragment was BglIIdigested and subcloned into BamHI-linearized plasmid pUC57-Sc_cat8 $\Delta$. As a result of further genetic manipulations recombinant plasmid pUC57-Sc_cat8 $\Delta$-natNT2 was constructed (Fig. 1). After that, deletion cassette was EcoRI/HindIII cut out from plasmid pUC57-Sc_cat8 8 -natNT2 and transformed into $S$. cerevisiae strain CMB.GS010. Transformants were selected on the solid YPD medium supplemented with $0.1 \mathrm{~g} / \mathrm{L}$ of nourseothricin after three days of incubation at $30^{\circ} \mathrm{C}$. Obtained transformants were examined by PCR using genomic DNA of recombinant strains as a template. Transformants with confirmed deletion of CAT8 were stabilized by altering cultivation in nonselective and selective media and once again examined by PCR. Fragments with predicted size $977 \mathrm{bp}$ and 1078 bp were amplified using pairs of primers (Ko780 (ACA AAC ACA TTG ACA CAT TC) / Ko781 (GAT GCA AAT GAT TAT ACA TG) and Ko782 (CTC TTA TTG ACC ACA CCT C) / Ko783 (CAA AGG AAC TGA AGT AAG TG)) homologous to the sequence of selective marker and regions outside from the 5' and 3' fragments used for recombination, respectively (Fig. 1).

Xylose fermentation of the isolated cat $8 \Delta$ strain was studied under oxygen-limited conditions (see "Materials and methods" section). It was found that defects of CAT8 gene leads to $9.5 \%$ increase in ethanol accumulation versus parental strain reaching $6.45 \mathrm{~g} / \mathrm{L}$ (Fig. 2; Table). Data of Table show that the strain cat $8 \Delta$ possessed increase in ethanol yield, rate of ethanol production and productivity of ethanol synthesis relative to the parental GS010 strain for 6, 20 and $12 \%$, respectively. Increased ethanol production from xylose was accompanied by decreased xylitol accumulation, while difference in amount of other byproducts of alcoholic fermentation such as glycerol and acetate was insignificant (Fig. 2). More probably, the increase of xylose fermentation rate is connected with restriction of a respiratory metabolism in cat 84 strain. Cell respiration of cat $8 \Delta$ cells in xylosecontaining media will be studied.

Thus, obtained results supported our hypothesis that Cat8 transcription factor is involved in the regulation of xylose alcoholic fermentation in engineered xylose-fermenting S. cerevisiae strain and the deficiency of this protein activates ethanol production from xylose. These results are in good agreement with our previous investigations that postulated involvement of Cat 8 in regulation of xylose alcoholic fermentation in naturally xylosefermenting yeast $O$. polymorpha [18]. 
A)

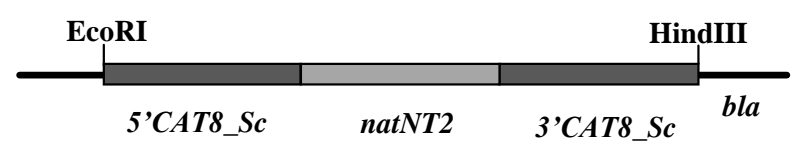

pUC57-Sc_cat8 $\Delta$-natNT2 6.082 bp
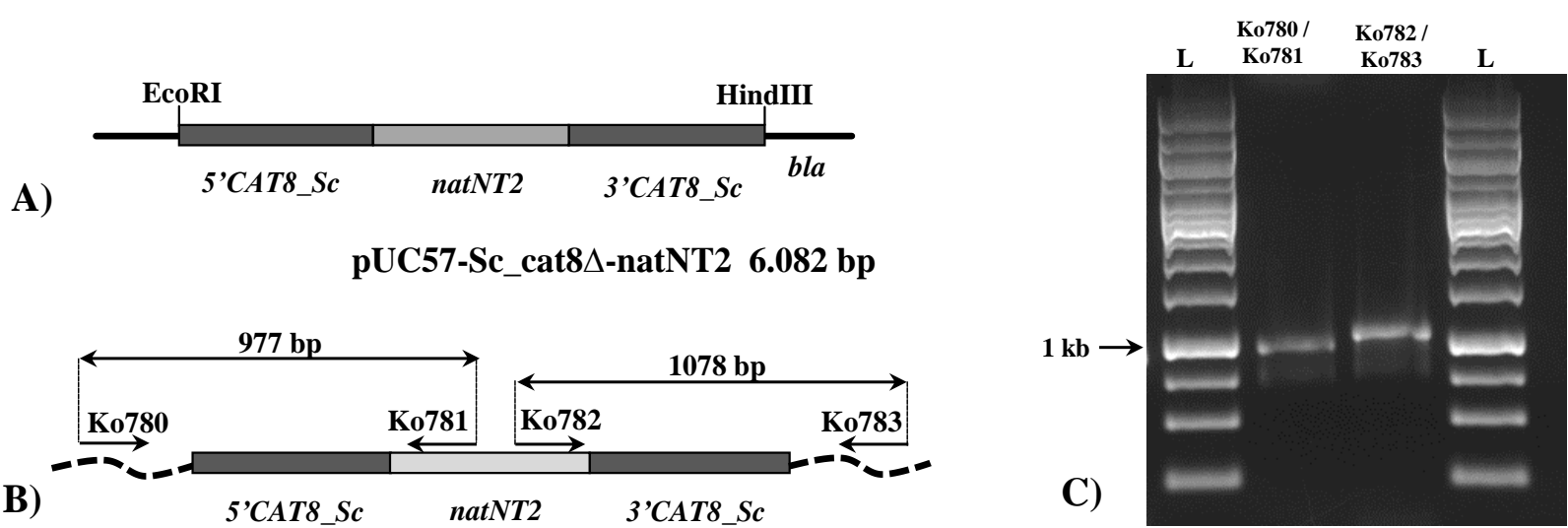

Fig. 1. A) scheme of plasmid pUC57-Sc_cat8D-natNT2; B) scheme of CAT8 deletion cassette for S. cerevisiae; C) PCR verification of the correct cassette integration into genome of the GS010 using primers Ko780/Ko781 or Ko782/Ko783 and genomic DNA of constructed deletion strain cat84 of S. cerevisiae as a template; L - $1 \mathrm{~kb}$ ladder.
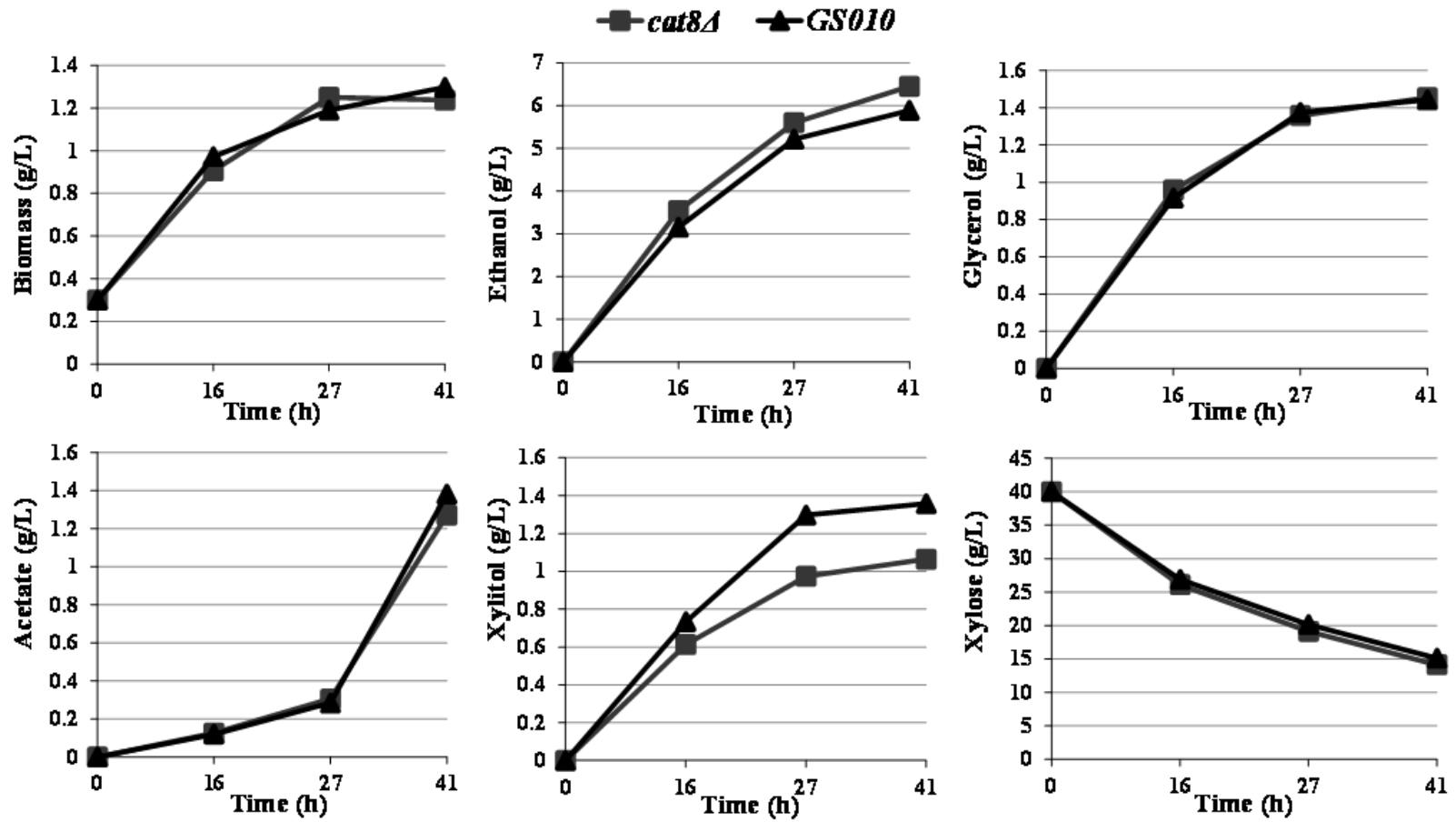

Fig. 2. Time courses of biomass accumulation, ethanol, glycerol, acetate, xylitol production and xylose consumption by $S$. cerevisiae cat 84 and GS010 during xylose fermentation. Represented data of typical fermentation experiment.

Table. Main parameters of xylose fermentation the S. cerevisiae GS010 and cat84 strains under oxygen-limited conditions at $30^{\circ} \mathrm{C}$

\begin{tabular}{|c|c|c|c|c|}
\hline Strain & $\begin{array}{c}\text { Ethanol } \\
(\mathrm{g} / \mathrm{L})^{*}\end{array}$ & $\begin{array}{l}\text { Ethanol yield } \\
\text { (g/g consumed } \\
\text { xylose) })^{* *}\end{array}$ & $\begin{array}{l}\text { Rate of ethanol pro- } \\
\text { duction } \\
\text { (g/g biomass } / \mathrm{h}) * *\end{array}$ & $\begin{array}{l}\text { Productivity of ethanol } \\
\text { synthesis } \\
(\mathrm{g} / \mathrm{L} / \mathrm{h})^{* *}\end{array}$ \\
\hline GS010 & $5.89 \pm 0.17$ & $0.240 \pm 0.004$ & $0.203 \pm 0.008$ & $0.197 \pm 0.005$ \\
\hline cat84 & $6.45 \pm 0.18$ & $0.254 \pm 0.005$ & $0.244 \pm 0.009$ & $0.221 \pm 0.006$ \\
\hline
\end{tabular}




\section{Conclusions}

The mutant of the xylose-fermenting $S$. cerevisiae strain with knock out of the CAT8 gene coding for transcriptional activator, has been con- structed. The cat $8 \Delta$ mutant showed $9.5 \%$ increase in ethanol production from xylose relative to parental strain.

\section{References}

1. Ragauskas A.J., Williams C.K., Davison B.H., Britovsek G., Cairney J., Eckert C.A., Frederick W.J. Jr., Hallett J.P., Leak D.J., Liotta C.L., Mielenz J.R., Murphy R., Templer R., Tschaplinski T. The path forward for biofuels and biomaterials. Science. 2006. Vol. 311. P. 484-489. doi: 10.1126/science.1114736.

2. Hong K.K., Nielsen J. Metabolic engineering of Saccharomyces cerevisiae: a key cell factory platform for future biorefineries. Cell. Mol. Life Sci. 2012. Vol. 69. P. 2671-2690. doi: 10.1007/s00018-012-0945-1.

3. Jansen M.L.A., Bracher J.M., Papapetridis I., Verhoeven M.D., de Bruijn H., de Waal P.P., van Maris A.J.A., Klaassen P., Pronk J.T. Saccharomyces cerevisiae strains for second-generation ethanol production: from academic exploration to industrial implementation. FEMS Yeast Res. 2017. Vol. 17 (5). doi: 10.1093/femsyr/fox044.

4. Moysés D.N., Reis V.C., de Almeida J.R., de Moraes L.M., Torres F.A. Xylose fermentation by Saccharomyces cerevisiae: challenges and prospects. Int. J. Mol. Sci. 2016. Vol. 17 (3). P. 207. doi: 10.3390/ijms17030207.

5. Matsushika A., Goshima T., Fujii T., Inoue H., Sawayama S., Yano S. Characterization of nonoxidative transaldolase and transketolase enzymes in the pentose phosphate pathway with regard to xylose utilization by recombinant Saccharomyces cerevisiae. Enzyme. Microb. Technol. 2012. Vol. 51. P. 16-25. doi: 10.1016/j.enzmictec.2012.03.008.

6. Xu H., Kim S., Sorek H., Lee Y., Jeong D., Kim J., Oh E.J., Yun E.J., Wemmer D.E., Kim K.H., Kim S.R., Jin Y.S. PHO13 deletioninduced transcriptional activation prevents sedoheptulose accumulation during xylose metabolism in engineered Saccharomyces cerevisiae. Metab. Eng. 2016. Vol. 34. P. 88-96. doi: 10.1016/j.ymben.2015.12.007.

7. Karhumaa K., HahnHägerdal B., GorwaGrauslund M.F. Investigation of limiting metabolic steps in the utilization of xylose by recombinant Saccharomyces cerevisiae using metabolic engineering. Yeast. 2005. Vol. 22. P. 359-368. doi: 10.1002/yea.1216.

8. Van Vleet J.H., Jeffries T.W., Olsson L. Deleting the paranitrophenyl phosphatase (pNPPase), PHO13, in recombinant Saccharomyces cerevisiae improves growth and ethanol production on D-xylose. Metab. Eng. 2008. Vol. 10. P. 360-369. doi: 10.1016/j.ymben.2007.12.002.

9. Bamba T., Hasunuma T., Kondo A. Disruption of PHO13 improves ethanol production via the xylose isomerase pathway. Amb. Express. 2016. Vol. 6. P. 4. doi: 10.1186/s13568-015-0175-7.

10. Kim S.R., Skerker J.M., Kang W., Lesmana A., Wei N., Arkin A.P., Jin Y.S. Rational and evolutionary engineering approaches uncover a small set of genetic changes efficient for rapid xylose fermentation in Saccharomyces cerevisiae. PLoS One. 2013. Vol. 8 (2). P. e57048. doi: 10.1371/journal.pone.0057048.

11. Kim S.R., Ha S.J., Wei N., Oh E.J., Jin Y.S. Simultaneous co-fermentation of mixed sugars: a promising strategy for producing cellulosic ethanol. Trends Biotechnol. 2012. Vol. 30. P. 274-282. doi: 10.1016/j.tibtech.2012.01.005.

12. Farwick A., Bruder S., Schadeweg V., Oreb M., Boles E. Engineering of yeast hexose transporters to transport D-xylose without inhibition by D-glucose. Proc. Natl. Acad. Sci. USA. 2014. Vol. 111. P. 5159-5164. doi: 10.1073/pnas.1323464111.

13. Haurie V., Perrot M., Mini T., Jenö P., Sagliocco F., Boucherie H. The transcriptional activator Cat8p provides a major contribution to the reprogramming of carbon metabolism during the diauxic shift in Saccharomyces cerevisiae. J. Biol. Chem. 2001. Vol. 276. P. 76-85. doi: 10.1074/jbc.M008752200.

14. Hedges D., Proft M., Entian K.D. CAT8, a new zinc cluster-encoding gene necessary for derepression of gluconeogenic enzymes in the yeast Saccharomyces cerevisiae. Mol. Cell. Biol. 1995. Vol. 15. P. 1915-1922. doi: 10.1128/MCB.15.4.1915.

15. Watanabe D., Hashimoto N., Mizuno M., Zhou Y., Akao T., Shimoi H. Accelerated alcoholic fermentation caused by defective gene expression related to glucose derepression in Saccharomyces cerevisiae. Biosci. Biotechnol. Biochem. 2013. Vol. 77 (11). P. 2255-2262. doi: 10.1271/bbb.130519.

16. Matsushika A., Goshima T., Hoshino T. Transcription analysis of recombinant industrial and laboratory Saccharomyces cerevisiae strains reveals the molecular basis for fermentation of glucose and xylose. Microb. Cell Fact. 2014. Vol. 13. P. 16. doi: 10.1186/1475-2859-13-16.

17. Scalcinati G., Otero J.M., Van Vleet J.R., Jeffries T.W., Olsson L., Nielsen J. Evolutionary engineering of Saccharomyces cerevisiae for efficient aerobic xylose consumption. FEMS Yeast Res. 2012. Vol. 12 (5). P. 582-597. doi: 10.1111/j.15671364.2012.00808.x.

18. Ruchala J., Kurylenko O.O., Soontorngun N., Dmytruk K.V., Sibirny A.A. Transcriptional activator Cat8 is involved in regulation of xylose alcoholic fermentation in the thermotolerant yeast Ogataea (Hansenula) polymorpha. Microb. Cell Fact. 2017. Vol. 16. P. 36. doi: 10.1186/s12934-017-0652-6.

19. Sambrook J., Fritsh E.F., Maniatis T. Molecular Cloning: A Laboratory Manual. New York: Cold Spring Harbor Laboratory Press, 1989. 253 p.

20. Gietz R.D., Woods R.A. Transformation of yeast by lithium acetate/single-stranded carrier DNA/polyethylene glycol method. Methods Enzymol. 2002. Vol. 350. P. 87-96. doi: org/10.1016/S0076-6879(02)50957-5.

21. Taxis C., Knop M. System of centromeric, episomal, and integrative vectors based on drug resistance markers for Saccharomyces cerevisiae. Biotechnique. 2006. Vol. 40. P. 73-78. doi: 10.2144/000112040. 
ДЗАНАєВА Л.С. ${ }^{1}$, ДМИТРУК К.В. ${ }^{1}$, СИБІРНИЙ А.А. ${ }^{1,2}$

${ }^{1}$ Інститут біології клітини НАН України,

Україна, 79005, м. Львів, вул. Драгоманова, 14/16, e-mail: dmytruk77@gmail.com

${ }^{2}$ Жешувський університет,

Польщза, 35-601, м. Жешув, Cwiklinskiej, 2

ТРАНСКРИПЦЙНИЙ ФАКТОР СаТ8 ЗАЛУЧЕНИЙ В РЕГУЛЯЦЮЮ ФЕРМЕНТАЦІЇ КСИЛОЗИ В PЕКОМБIHАНTHOMУ ШTAMI SACCHAROMYCES CEREVISIAE

Mema. Мета даної роботи полягає в конструюванні cat84 на основі ксилозоферментуючого штаму S. cerevisiae та аналізі алкогольної ферментації ксилози. Методи. Було сконструйовано касету для делеції гена $C A T 8$, що містить маркерний ген natNT2, фланкований 5' та 3' некодуючими ділянками цільового гена. Штам cat84 було відібрано після трансформації сконструйованою касетою на середовищі з антибіотиком норзеотрицином. Алкогольну ферментацію проводили на мінеральному середовищі з додаванням ксилози за умов обмеженої аерації. Результати. Ксилозоферментуючий cat84 штам S. cerevisiae було сконструйовано за допомогою гомологічної рекомбінації делеційної CAT8 касети з цільовими послідовностями геному штаму GS010. У порівнянні з батьківськім штамом, cat84 характеризувався підвищеною продукцією етанолу, виходом етанолу, питомою продукцією та продуктивністю етанолу на 9,5; 6; 20 та 12 \%, відповідно. Висновки. Було сконструйовано ксилозоферментуючий мутант $S$. cerevisiae 3 делецією гена $C A T 8$, що кодує транскрипційний активатор. Штам cat84 характеризувався підвищеною на 9,5\% продукцією етанолу з ксилози у порівнянні з батьківським штамом.

Ключові слова: алкогольна ферментація, ксилоза, S. cerevisiae, Cat8. 